\title{
Understanding The Problem of Social Cost
}

\author{
BRETT M. FRISCHMANN* \\ Benjamin N. Cardozo School of Law, Yeshiva University, New York City, USA
}

\author{
ALAIN MARCIANO** \\ Department of Economics, University of Montpellier 1 and LAMETA UMR 5574, Montpellier, France
}

\begin{abstract}
Coase always expressed dissatisfaction with neo-classical economics and advocated for a new approach. Rather than using toy mathematical models built from unrealistic, idealized assumptions, Coase preferred to study real-world contexts, including actual legal cases. He demonstrated the utility of his approach in 'The Problem of Social Cost'. Yet almost all of Coase's contemporaries completely ignored, Coase's call for a new approach and his sustained use of legal cases to illustrate his arguments and to situate his analysis in reality. In this paper, we show that the profession interpreted Coase's seminal article exactly the opposite of what he had intended, and reduced his analytical contributions to a toy model of the exact sort he was criticizing. This ironic history of the most cited article both in law and in economics helps us understand the development of ideas within both fields and how disciplinary blinders shape intellectual progress.
\end{abstract}

\section{Introduction}

Since his first published article in 1937, Coase expressed dissatisfaction with neo-classical economics and advocated for methodological change that involves two related methodologies. First, Coase insisted on the need to use a comparative institutional analysis based on the 'powerful metric of transaction costs' (Cole, 2014; Medema, 2014b). Second, Coase was convinced by the need to ground theoretical analyses in empirical studies and opposed to what he later named 'blackboard economics' (Coase, 1988, 19, 28, 179; 1992, 714). ${ }^{1}$ He called for careful attention to real-world context and critiqued the use of abstract models divorced from reality. Thus, rather than using mathematical models built from unrealistic, idealized assumptions, Coase preferred to use cases (case studies). This is evidenced in works such as 'The Origin of the Monopoly of Broadcasting in Great Britain' (1947), 'Wire Broadcasting in Great Britain' (1948), British Broadcasting: A Study in Monopoly (1950), 'The Federal Communication

\footnotetext{
*E-mail: frischma@yu.edu

**E-mail: alain.marciano@univ-montp1.fr

1 On this point see, for instance, Bertrand (2009, 2011), Halpin (2011).
} 
Commission' (1959) and, of course, 'The Problem of Social Cost' (hereinafter PSC). The latter being the most spectacular instance of how Coase envisaged this new approach.

PSC involves back-and-forth movement between the numerical example Coase discussed in sections III and IV and the legal cases introduced in section V (see table 1). The numerical example was used in complement with the legal case and, reciprocally and complementarily, the legal cases were means to illustrate and clarify the result reached through the numerical example. Further, Coase made an interesting structural move by evaluating legal decision making in light of the toy model world and reevaluating it in light of the real world. What seems like a series of ad hoc, legal decisions based on factors an economist would consider irrelevant, especially in the imaginary world of a costless pricing system (section V), suddenly looks more ordered and rational, though still imperfect, when one understands the world to be rife with transaction costs (section VII). Thus, Coase not only used the legal cases to illustrate his conceptual points about the problem and its reciprocal nature, but also to illustrate the need for the new comparative approach he advanced.

Economists were attracted to the first four sections and less interested in parsing the details of the remaining sections. The full article is forty-four pages. The first four sections comprise only seven and a half pages, and the fifth section is about the same length. The content of the fifth section-description and analysis of legal cases-was undoubtedly foreign to most economists in a period when 'law and economics' was in its infancy. Thus, when confronted with further illustration of the problem with legal case descriptions in section five, economists, attracted to the first four sections, were less interested in the details of the remaining sections. As a consequence, the originality of the method-using legal cases to clarify and illustrate a technical point-appeared less revolutionary than the conclusion Coase reached-harmful effects are reciprocal in nature and equivalent results occur in a costless pricing system with well-defined property rights regardless of how such rights are assigned. And, of course, the call for $A$ Change of Approach that arrived only at the end of the paper (section X), after being demonstrated in the intermediate sections that most economists ignored, was no more visible than Coase's criticisms of the assumption of zero transaction costs, of the ideal world analyses and of laissez-faire.

The reception of PSC has already been studied and certain forms of misinterpretations have already been emphasized (see in particular McCloskey, 1998; Medema, 2013, 2014a, 2014b, 2014c). In this paper, we focus on a specific aspect that has not, to our knowledge, been discussed, namely Coase's unambiguous plea for a new approach built upon comparative analysis of social arrangements and grounded in real-world contexts. Indeed, the scholars who praised or criticized Coase's ideas missed the unequivocal call for a substantial change of methodology, ignored the empirical nuances of Coases' article, emphasizing only its non-empirical part and reducing it, as Coase eventually 
Table 1

\begin{tabular}{|c|c|}
\hline Section & Summary/basic takeaway \\
\hline I. The problem to be examined & $\begin{array}{l}\text { The problem is the conclusions reached by conventional economic } \\
\text { analysis of situations involving negative externalities. }\end{array}$ \\
\hline $\begin{array}{l}\text { II. The reciprocal nature of the } \\
\text { problem }\end{array}$ & $\begin{array}{l}\text { Contrary to conventional economic analysis, the harms associated } \\
\text { with negative externalities are jointly produced and caused by } \\
\text { reciprocal, interdependent actions and actors. }\end{array}$ \\
\hline $\begin{array}{l}\text { III. The pricing system with } \\
\text { liability for damage }\end{array}$ & $\begin{array}{l}\text { Assuming a costless pricing system, Coase analyzes the allocation of } \\
\text { resources among cattle-raising and farming when the cattle-raiser is } \\
\text { liable for crops destroyed by straying cattle and taking into } \\
\text { account various factors, such as the cost of fencing. }\end{array}$ \\
\hline $\begin{array}{l}\text { IV. The pricing system with no } \\
\text { liability for damage }\end{array}$ & $\begin{array}{l}\text { Assuming a costless pricing system, Coase shows that the same } \\
\text { allocation of resources would result when the cattle-raiser is not } \\
\text { liable for crops destroyed by straying cattle. }\end{array}$ \\
\hline $\begin{array}{l}\text { V. The problem illustrated } \\
\text { anew }\end{array}$ & $\begin{array}{l}\text { Coase illustrates the points made in the previous three sections } \\
\text { through a series of actual real-world cases. }\end{array}$ \\
\hline $\begin{array}{l}\text { VI. The cost of market } \\
\text { transactions taken into } \\
\text { account }\end{array}$ & $\begin{array}{l}\text { After unambiguously disavowing the assumption of a costless pricing } \\
\text { system as unrealistic and emphasizing the significance of real-world } \\
\text { transaction costs, Coase emphasizes that economic analysis of the } \\
\text { problem requires comparative, realistic, and patient analyses of } \\
\text { alternative social arrangements for dealing with the problem. }\end{array}$ \\
\hline $\begin{array}{l}\text { VII. The legal delimitation of } \\
\text { rights and the economic } \\
\text { problem }\end{array}$ & $\begin{array}{l}\text { Coase discusses a series of cases to argue that when delineating rights, } \\
\text { the legal system effectively but imperfectly balances the full range } \\
\text { of benefits and costs with an appreciation of the reciprocal nature } \\
\text { of the problem and also that economists 'seem to be unaware of all } \\
\text { of this'. }\end{array}$ \\
\hline $\begin{array}{l}\text { VIII. Pigou's treatment in 'the } \\
\text { economics of welfare' }\end{array}$ & $\begin{array}{l}\text { Using various examples, Coase criticizes Pigou for failing to do what } \\
\text { Coase advocates, namely when 'comparing alternative social } \\
\text { arrangements, the proper procedure [for an economist] is to } \\
\text { compare the total social product yielded by the different social } \\
\text { arrangements'. }\end{array}$ \\
\hline IX. The Pigouvian tradition & $\begin{array}{l}\text { Conventional economics in the Pigouvian tradition errs in its analysis } \\
\text { and policy conclusions (supporting liability, taxes or bounties for } \\
\text { those who 'produce' harmful effects) because of its failure to do } \\
\text { what Coase advocates (see above). }\end{array}$ \\
\hline X. A change of approach & $\begin{array}{l}\text { 'It is my belief that the failure of economists to reach correct } \\
\text { conclusions about the treatment of harmful effects cannot be } \\
\text { ascribed simply to a few slips in analysis. It stems from basic } \\
\text { defects in the current approach to problems of welfare economics. } \\
\text { What is needed is a change of approach'. }\end{array}$ \\
\hline
\end{tabular}

complained, to its 'most abstract part'. ${ }^{2}$ But Coase linked the misinterpretation of his work to Stigler's Coase theorem ${ }^{3}$ and the impact it had on economists (and legal scholars). Stigler, however, was only one among many who perceived

2 http://www.coase.org/coaseinterview.htm. see also Coase, 1988; 1992.

3 The theorem was invented by Stigler who wrote that ' $\mathrm{t}$ ] he Coase theorem thus asserts that under perfect competition private and social costs will be equal' $(1966,113)$. 
and treated Coase's article in the same reductionist way. ${ }^{4}$ The phenomenon dated back to the first references to PSC, made just after its publication. This is what we show in this paper. We examine the reception of PSC in the 1960s to document the ironic story of how PSC was transformed from 'a learned paper, replete with case law' (Mishan, 1965, 29) into an abstract paper divorced from context and how the legal, comparative, and contextual dimensions of Coase's analysis were systematically ignored. We show that the profession ironically interpreted Coase's seminal article exactly the opposite of what he had intended, and essentially, in doing so, reduced his analytical contributions to a toy model of the exact sort he was criticizing.

We adopt a narrow focus for two reasons. First, it allows us to dig deeply into the articles that immediately followed publication of Coase's seminal article and thus to assess its initial reception; these papers set the path for the reputation Coase had among economists. Second, in the early 1970s, 'law and economics' was recognized and being established in particular at Chicago. This recognition assumed three forms. First, the economists involved in the field were developing relatively technical models (Becker, 1968; Ehrlich, 1973; Landes, 1968, 1971, for instance). Notably, they drew the field in a direction that was different from what Coase did. Second, more and more legal scholars (Richard Posner and Richard Epstein, for instance) were involved in the field; their analyses incorporated legal content and expertise in a more sophisticated fashion, at least from a legal perspective, than Coase. Third, under the influence of economists (Becker and Landes) and legal scholars (Posner), the field became an 'economic analysis of law' which differs from Coase's 'law and economics' (on the differences see, for instance, Harnay and Marciano, 2009). To some extent, it was too late for Coase's article to be viewed as more than the 'result' embodied in the 'Coase theorem'.

As a matter of economic history, it is important to identify how such transformations occur, especially with respect to seminal articles such as this one. Suffice it to say that Coase is not the only scholar subject to such actions. This ironic history of the most cited article both in law and in economics helps us understand the development of ideas within both fields and how disciplinary blinders shape intellectual progress.

\section{Contemporaneous interpretations of PSC within the emerging literature about externalities}

When Ronald Coase's PSC was published in $1961,{ }^{5}$ very few economists were interested in externalities, ${ }^{6}$ especially from a non-Pigovian

4 One of the rare exceptions is Demsetz's contemporaneous papers, discussed below.

5 The Journal of Law and Economics suffered from some delays (Kitch, 1993). This explains that the first scholars who referred to this specific paper from Coase were close acquaintances.

6 During the 1950s, few articles (Meade, 1952; Scitovsky, 1954; and to a lesser extent, Bator, 1957) had been devoted to a phenomenon perceived as 'unimportant' (Scitovsky, 1954, 145) and 'probably rare' 
perspective. ${ }^{7}$ This means that PSC was one of the first contributions to discuss the problems raised by negative externalities, or rather 'harmful effects', as Coase named them. But this also implies that very few scholars knew Coase's article. It is thus no surprise if references to PSC were not frequent. ${ }^{8}$ Even less frequent were those that discussed PSC and referred to liability. The first mentions made to the assignment of rights and corresponding allocation of liability in connection with PSC appeared in two essays-Ralph Turvey's 'On Divergences between Social Cost and Private Cost' (1963) and Stanislaw Wellisz' 'On External Diseconomies and the Government-Assisted Invisible Hand' (1964). These articles surveyed the limited but increasing in quantity and quality literature on externalities. ${ }^{9}$ Of course, one would think that Turvey and Wellisz were supposed to give readers a precise-that is, as faithful as possible-idea of the content of the papers they were presenting. Medema (2014) shows that this was not the case.

Like Coase, Turvey had studied and then taught at the London School of Economics, where he had made the acquaintance of Coase; he was one of Coase's students, and he had also studied economics with James Meade and William Baumol. In addition, Turvey had written, The Economics of Real Property (1957), in which he came quite close to the negotiation result Coase had put forward in PSC (see Medema, 2014). It is not a surprise that Turvey paid attention to the burgeoning literature on externalities and, in particular, to Coase's article. It was in 1963 that he published his 'attempt to synthesize and summarize the main ideas' (Turvey, 1963, 309) included in '[t]hree recent articles ... Professor Coase's "The Problem of Social Cost", then Davis and Whinston's "Externalities Welfare and the Theory of Games" ... Buchanan and Stubblebine's "Externality"' (1963, 309).

(1957, 42). Even after Paul Samuelson published his articles on the pure theory of public expenditures $(1954,1955,1958)$, that marked a turning point in economics and although more papers were written, the topic remained marginal.

7 One exception is Buchanan (1956) who considered the problem of social cost, and echoed Frank Knight's 1924 comment on the arguments developed by Pigou in The Economics of Welfare.

8 Despite conventional wisdom, The Problem of Social Cost did not become 'immediately' famous or 'infamous' (In his Nobel lecture, Coase spoke of the 'infamous Coase Theorem', www.nobelprize.org/nobel_prizes/economic-sciences/laureates/1991/coase-lecture.html). It took some time before Coase's article acquired a reputation and visibility.

9 Around the same period, the first articles analyzing externalities in environmental contexts were published. The Problem of Social Cost was used in this literature. But, even if property rights were mentioned, Coase's work was rarely linked to the legal dimension of the problem. Most of the time, Coase was cited for having demonstrated that market mechanisms could be used to cure market failures and for having stressed the virtues of bargaining. Emery N. Castle, for instance, in The Market Mechanism, Externalities, and Land Economics published in 1963, analyzed how 'the literature on external economies, diseconomies, and indivisibilities' could explain how to use different institutional arrangements- the market and nonmarket institutions-to manage natural resources. He cited The Problem of Social Cost and stressed the role of property rights and other institutions that could be used for natural resource management but did not link Coase's works to rights and institutions. 
Although there were only three papers, the contrast between them is striking. Davis and Whinston's and Buchanan and Stubblebine's articles shared the same features: They were built around a mathematical, axiomatized model and did not present any empirical data or legal cases to illustrate their claims. They are quite different from PSC, which employed a very specific, and original, approach. Coase did not rely on a mathematical, axiomatic model but combined a numerical example with legal cases. This gave Coase's paper a strong empirical dimension, stronger at least than the two other papers Turvey discussed. ${ }^{10}$

But Turvey did not choose to preserve the specificity of Coase's article. $\mathrm{He}$ included the three articles in a single theoretical, even if nonaxiomatic, and diagrammatic presentation ${ }^{11}$ of the problem that was along the lines of the models built by Davis/Whinston and Buchanan/Stubblebine. He drew Coase's analysis-and was the first to do that-toward the mathematical side of Davis/Whinston and Buchanan/Stubblebine. One positive way of presenting this choice would be to say that Turvey was trying to generalize Coase. But, by making such a choice and only focusing on the toy model (numerical example coupled with costless pricing system), Turvey ignored the rest of Coase's article, that is, sections five through ten! He severed the link between the two complementary aspects of Coase's approach-the numerical example and the empirical illustrations, and he failed to appreciate the consequences of Coase's arguments about comparing costly real-world systems.

Reductionism directly appears in the situations Turvey analyzed, which involved a simple, unidirectional relationship: 'A ... the person, firm or group (of persons or firms) ... imposes a diseconomy [... on ...] B the person, firm or group which suffers it' (Turvey, 1963, 309). This ignored Coase's initial conceptual point about reciprocal causation and its demonstration in the various legal cases that Coase discussed. In other words, it ignored the idea that B could have contributed to the diseconomy, or harmful effects in Coase's language. Turvey seemed to adopt the framing Coase used in his numerical example but not the more detailed analysis that followed. This appears to confirm our view, noted earlier, that Turvey was interested in proposing an axiomatization of Coase's numerical example rather than in the legal and empirical dimensions of Coase's analysis.

Similarly, when Turvey briefly considered the relevance of the assignment of liability, he only compared superficially the case when A 'is liable to compensate B for actual damages caused by his activity' (Turvey, 1963, 310) to the case

10 We do not claim that Coase's paper was a strong empirical paper. In fact, from the perspective of a modern empiricist, there are many problems with Coase's particular reliance on cases-for example, his method of selecting cases, to name just one. This is beside the point. Coase advanced a change in method and made an effort to demonstrate his new approach through the grounding of his analysis in the facts of real-world cases.

11 A diagram that became the standard one for treating Coase's result (we thank Steve Medema for having reminded us this very significant point). 
when 'there is no such liability' (Turvey, 1963, 310). Turvey did not go very far. Like Coase, he used 'liability' as a synonym of 'being obliged to compensate' another individual. But Turvey did not take the further steps taken by Coase, or even seem to appreciate that Coase had done so. That the legal cases provided detailed grounding in factual contexts escaped Turvey's notice.

Even more surprising, Turvey concluded his analysis by noting that 'when negotiation is possible, the case for government intervention is one of justice not of economic efficiency; when it is not, the theorist should be silent and call in the applied economist' (Turvey, 1963, 313; emphases added). ${ }^{12}$ This suggests two major misinterpretations, if not mistakes. First, Turvey apparently missed the critical distinction between costless and costly negotiation; when negotiation is possible but costly, the case for government intervention is one of comparative institutional analysis in context, presumably still on the basis of efficiency. Buchanan and Stubblebine made the same 'mistake' in their article, 'Externality'. Buchanan and Stubblebine included a reference to Coase and to what became known as the main result of PSC, noting that Coase had demonstrated that 'the same 'solution' [in terms of allocation of resources] will tend to emerge out of any externality relationship regardless of the structure of property rights, provided only that the market process works smoothly' (1962, 383; emphasis added). The reference, laconic and succinct, did not acknowledge the other, more subtle dimensions of Coase's analysis. 'Smoothly' does a lot of work to gloss over and ultimately ignore Coase's call for comparative institutional analysis of alternative social arrangements in real-world contexts.

Second, Turvey gave the impression that none of the papers he was discussing had been an exercise in applied economics. He did not allude to the fact that Coase's article was precisely the work of an applied economist and his work had so far always been applied. Everything was described by Turvey as if Coase's article had been of the same nature as Buchanan and Stubblebine's and Davis and Whinston's- that is technical, abstract, and model-based papers. In other words, it was not only the Chicagoans who ignored the comparative and empirical part of his analysis. And it was not only after Stigler had put forward the Coase theorem. The first survey that presented PSC did exactly what Coase complained that the Chicago people did-reading only 7 pages of his paper. The second survey- Wellisz's-written about the same issue adopted exactly the same perspective on Coase as Turvey's. This is what we now show.

12 Turvey did not seem to agree with Coase's result. He admitted that '[e]fficient resource allocation requires the imposition of a liability upon A only if we can show that inertia, obstinacy, etc. inhibit A and B from reaching a voluntary agreement' $(1963,310)$, that is only if there are these types of transaction costs. From this perspective, as one of the referees suggested, this implies a reference to transaction costs. But as we have suggested, Coase argued that such costs would trigger a comparative analysis and not reflexive imposition of liability in the name of efficiency. Turvey insisted that that it does not make any difference in terms of 'efficiency', and that what matters is justice and fairness not efficiency: 'for damages caused is a matter of fairness, not of resource allocation' $(1963,310)$. 
In 1964, Stanislas Wellisz published 'On External Diseconomies and the Government-Assisted Invisible Hand', a paper in which he analyzed the same literature on externalities as Turvey-Coase's, Buchanan/Stubblebine's and Davis/Whinston's papers-nonetheless adopting a different approach compared to Turvey: rather than summarizing or synthesizing the papers, Wellisz presented them one after the other. He therefore did not subsume Coase's article in a general model. He did not try either to build a model out of the numerical example proposed by Coase. However, Wellisz treated Coase exactly as Turvey had done. He similarly severed the link between the numerical example and the legal illustrations and analysis. The eight pages Wellisz devoted to Coase ${ }^{13}$ focused only on the numerical example Coase had used in PSC and made no explicit or genuine reference to the legal cases or Coase's extensive discussion of them. ${ }^{14}$ The reason Wellisz gave to justify his choice was significant: the numerical example helped ' $[\mathrm{t}$ ] clarify the reasoning underlying his conclusions in the railway case' (1964, 348; emphasis added). Thus, in sharp contrast with Coase who had used the legal cases to clarify and complement the numerical example, Wellisz used the numerical example without the legal examples as if it were sufficient

The reductionism of Wellisz's approach echoes Turvey's. First, Wellisz studied the simple relationship in which one individual, in that case a train, causes a damage to another one, a farmer. As was the case in Turvey's paper, all the subtleties present in the legal cases discussed by Coase disappeared in the presentation made by Wellisz. Second, Wellisz compared cases in which 'damage liability is imposed' $(1964,349)$ to 'no-liability regime[s]' (1964, 349). His analysis was not substantively different from Turvey's analysis, or, for that matter from what Coase had done in the first four sections of his paper. Again, the major substantive difference is that Coase did not stop at that point-there were six more sections to Coase's paper.

Those two surveys presented PSC in exactly the same manner. They restricted their views to the numerical example used by Coase and ignored the empirical and comparative parts of his paper; they adopted a strictly deductive approach while Coase's approach had been inductive as well as deductive (see Maki, 1998; Medema, 1994). As suggested in the previous section, the way Coase structured his paper may have made this possible. But possible did not mean unavoidable or justifiable.

The role of property rights and the possible link between 'liability' and 'property rights' was admittedly vague in PSC. It was also totally absent from

13 Eight out of 19 pages, almost half of the paper.

14 The allusion he made- 'Coase takes great care to show that if courts award excess damages, they are likely to curtail useful activities in order to protect the interests of the victims of external diseconomies'. (Wellisz, 1964, 348)—was too vague to be visible. The importance given to the figures and abstract presentation of the numerical example pointed in another direction. 
Turvey's and Wellisz's articles. Less than a handful of scholars mentioned property rights in a discussion of Coase and in reference to PSC. Besides Buchanan and Stubblebine, mentioned above, Milliman, who argued that '[v]ery often the pricing system itself may take into account many types of spillover losses and gains' $(1962,215)$, had cited Coase for having 'ma[de] this point in convincing fashion' in PSC $(1962,215)$. But neither the first two, nor the latter had said much about Coase's way of analyzing property rights and the link with liability. It was Harold Demsetz who, in 'The Exchange and Enforcement of Property Rights' (1964), first connected, even if allusively, Coase, property rights and liability.

This makes perfect sense. Demsetz was closer to Coase than Wellisz and even than Turvey. He was a Chicago economist-he was with the Graduate School of Business and taught at the Law School of the University of Chicago when he published his article. ${ }^{15}$ Also, Demsetz was closer to Coase's law-and-economics perspective than Turvey and Wellisz. In 1961, one of his papers was published in the Journal of Law and Economics. In 1962, he had written an article, connected to his $\mathrm{Ph}$. D. thesis, about the role of information and transaction costs. More broadly, Demsetz was already convinced by the importance of property rights, and the need to study their origins and their impact on economic activities and their role in solving market failures. By contrast with Turvey and Wellisz, Demsetz's research agenda in law-and-economics was structured around property rights and externalities and intersected with Coase's. This affected how Demsetz used and referred to Coase.

In some respects, there are not differences between how Demsetz, Turvey and Wellisz treated PSC. In particular, Demsetz did not go much farther than them in terms of how he defined and analyzed the impact of liability on individual actions. Undoubtedly, Demsetz stressed that assigning liability to one party or to the other could have consequences on their respective behaviors (Buchanan and Stubblebine, 1962; Frischmann and Lemley, 2007). But, globally, he also insisted that the assignment of liability had no impact on the efficiency of the interaction. This was when he referred to Coase and discussed his result: 'Coase points out the efficiency of the solution with respect to the number of cattle and the size of the crops in the absence of exchange costs is independent of whether the farmer or rancher is legally liable for the damage' $(1964,12)$ or ' $[\mathrm{w}]$ hichever way the rights are initially assigned, the outcome of the subsequent bargaining will be that which maximizes the value of output' $(1964,12)$. In other words, Demsetz went directly to the result put forward by Coase. One might conclude this means that Demsetz only used the first three sections of PSC.

15 Demsetz graduated from Northwestern University in 1959, then went to the University of Michigan and at UCLA before moving to the University of Chicago in 1963. He was the first economist with a position at the University of Chicago to refer to PSC. 
But that would not be enough to characterize Demsetz's approach and article. Demsetz was not interested in the result put forward by Coase only or per se. He was rather interested in what it meant from a perspective of a theory of property rights. Indeed, immediately after having summarized Coase's result, Demsetz explained why such result was important. His explanation was totally different from what the other commentators had done in that it departed from the result itself. PSC was not useful because it showed that legal rules had no impact on the efficiency of interactions between a tortfeasor and a victim. Rather, the crucial point was the existence or reality of positive exchange costs, and what they implied or meant. First, acknowledging the existence of such costs meant that a comparative institutional analysis was required-'[f] $]$ or now Coase has shown that if exchange costs are positive, it is necessary to ask whether government can take the harmful effects of an action into account at less cost than can the market' (Demsetz, 1964, 12). Second, Demsetz also suggested that external—or 'side'-effects as he named them could not always been internalized-if exchange costs are positive, one may ask 'if the resulting resource realignment is worth the cost of taking the side effects into account at all' $(1964,12)$; that was a point that Coase had noted at the very end of PSC but that Demsetz was the first to seriously refer to. Then, third, Demsetz found Coase's analysis important because of what it implied for a theory of property rights. This is crucial, and he devoted the rest of his paper to this argument: individuals need and develop property rights precisely because there are positive exchange costs. Property rights appear as a means to economize on exchange costs. Obviously, Demsetz drew Coase further than PSC. He was the first-and the only one in this period. Just after him arrived George J. Stigler who was, for his part, more interested in the analytical dimension of PSC; that is, on what it meant for a theory of markets.

Stigler, the 1982 Nobel Prize winner, became acquainted with Coase's arguments when Coase presented 'The Federal Communications Commission' (1959) at the University of Chicago. He also attended the dinner party at Aaron Director's place to which Coase had been invited to explain more precisely his views. ${ }^{16}$ Stigler was responsible for the hiring of Coase at the University of Chicago Law School in 1964. He is also well known for having 'invented' the Coase theorem in 1966 . We thus may reasonably infer that he was perfectly

16 As is well known, when Coase presented 'The Federal Communications Commission' in a seminar for the economists of the University of Chicago, a number of the attendees thought that the 'part' regarding the fact that the allocation of resources is independent from the legal rules was 'erroneous' (http://www.nobelprize.org/nobel_prizes/economic-sciences/laureates/1991/coase- bio. html) because it was 'contravening Pigou's analysis'. (Coase, 1996, 810). As Stigler recounted the story, at the beginning of the evening, all 'strongly objected to this heresy' $(1988,76)$. But '[i]n the course of two hours of argument, the vote went from 21 against and one for Coase to 21 for Coase'. (Stigler, 1988, 76). To Stigler, it was such an 'exhilarating event' $(1988,76)$, that he 'lamented afterward that we had not had the clairvoyance to tape it'. 
aware of the content of PSC and of the nature of Coase's arguments. Yet none of this background knowledge surfaces in Stigler's discussion of PSC in his book, The Theory of Price. Stigler made many references to 'liability;' the most important one was when he wrote that ' $[t]$ he fundamental symmetry in the relations of cattle and grain farmers, no matter where the law places the liability for damages, deserves elaboration' $(1966,112)$ and then ' $[t]$ he manner in which the law assigns liability will not affect the relative private marginal costs of cattle and grain' (1966, 113; emphasis in original). But these references never ventured beyond the toy model (costless pricing system). Like the other economists we have discussed so far, Stigler did not appreciate Coase's call for and demonstration of a new approach. He ignored the bulk of Coase's article and, restricting himself to the imaginary world of a costless pricing system, could not view the importance - and for that matter necessity — of a comparative analysis, much less mention Coase's suggestion that economists had something to learn from the law. ${ }^{17}$

Like the others, Stigler was interested only in the general, theoretical, and abstract result that could be drawn from the first third of Coase's article and that, as a result of Stigler's label, became known as the Coase theorem (Stigler, 1966, 113). And the explanation is straightforward. To Stigler, the result embodied in the 'Coase theorem' - and this is why he presented it as a theorem-was of the same nature as 'the fundamental theorem of competitive markets' (Stigler, 1989, 632). It used different words to present the standard neo-classical result 'that homogeneous resources receive equal returns in all uses' (Stigler, 1989, 632). As an economist, there was no real need to go beyond that step. In particular, the empirical side of Coase analysis-and therefore the need to use legal cases to illustrate the theorem-was not an issue. ${ }^{18}$

17 Yet, in 1972, Stigler wrote that economists and legal scholars should talk one another, and he credited the need for such discussions to Coase: 'Coase['s] analysis has emphasized the urgent need in economics for a general theory of transaction costs. The development of a theory of costs is a task for economists, but an integral part of that task is the understanding of the legal processes which may be employed' $(1972,12)$. Stigler said this in the very first article published in the Journal of Legal Studies, launched by Richard Posner as an alternative to the Journal of Law and Economics then edited by Coase (on the differences between Coase and Posner, see, in particular, Harnay and Marciano, 2009). It is therefore another irony that Stigler used Coase as an argument to promote a necessary discussion between economists and legal scholars in an article published in a journal defending a type of interaction between law and economics that was not the one defended by Coase.

18 In later articles, when he presented the 'Coase Theorem', Stigler always stuck to the example-the case of the cattle rancher and the farmer-used by Coase (1989, for instance). He insisted that the result was 'incredible' and unrealistic-' [ $t$ ] he world of zero transaction costs turns out to be as strange as the physical world would be with zero friction' $(1972,12)$. However, to Stigler, this has never been a problem because, as he put it, one should be careful to distinguish the 'logic' of the theorem from its empirical 'validity'. These are two different levels of analysis (1989; 630-631). To him, from the perspective of a 'theory of price', PSC operated at the abstract level through the logical demonstration of the result. Its empirical validity was a second step, not unimportant but certainly less important, and we have no reason to believe that Stigler even noticed the empirical dimension of PSC. 
More surprisingly, the empirical dimension of Coase's analysis-and his call for a new approach-did not seem to be an issue for G. Warren Nutter either. The surprise comes from the fact that, a Chicago economist himself, Nutter was more on the side of the 'old Chicago School'-à la Knight - than on the side of the 'new Chicago School'- that was represented by Stigler. Nutter knew Coase for having contributed to hire him at the University of Virginia, ${ }^{19}$ when Nutter was co-directing the Thomas Jefferson Center with Buchanan. ${ }^{20} \mathrm{He}$ thus had seen and spent some time with Coase in Charlottesville, especially when Coase wrote PSC. Nutter was also linked to Chicago, having been the first Ph.D. student of Milton Friedman. ${ }^{21}$ It was Friedman who convinced him of the validity of the Coase theorem and led him to write 'A New Proof of the Coase Theorem' instead of 'The Fallacy of the Coase Theorem'. ${ }^{22}$ The paper was eventually titled 'The Coase Theorem On Social Cost: A Footnote' and published in the Journal of Law and Economics in 1968. In this short piece, Nutter's aim was to defend the Coase Theorem and show that Calabresi had been wrong in his 1965 article when he had claimed that liability rules do not affect the allocation of resources in the short run but do so in the long run. Nutter stressed that Coase 'showed that, whenever the cost of market transactions can be neglected, the "damaging agent" will make the same calculation of marginal cost whether charged with responsibility for damages or not' $(1968,503)$. Nutter argued by contrast to what Calabresi had shown, this was right in the long as well as in the short run. So he concluded: 'the Coase theorem applies to the long-run as well as the short-run allocation of resources' (Nutter, 1968, 504). Therefore, to Nutter, showing that Calabresi was wrong meant that the Coase theorem was valid and implied that Coase was right. To Nutter, there was no difference between Coase's PSC and Stigler's 'Coase theorem'. However, to reach such a conclusion, Nutter explicitly based his analysis on the toy model frame and specifically 'the case of the straying cattle' $(1968,504)$. To Nutter, PSC involved two things, a

19 Buchanan recounted that 'Nutter deserves full credit for the discovery, recruitment, and appointment of Coase. Warren had participated, perhaps in the summer of 1957, in one of the long conferences sponsored by the William Volker Fund. Coase was one of the three main speakers at the conference ... Warren Nutter returned to Charlottesville mightly impressed with Coase, and he immediately commenced to examine the prospects of prying Coase away from the University of Buffalo... After lengthy, and sometimes tortuous negotiations, the deal was made, and after a full year's delay, Coase shifted to Charlottesville' (REF).

20 The Thomas Jefferson Center for Studies in Political Economy and Social Philosophy was established in 1957 by Buchanan and Nutter. Buchanan was the first executive director. Nutter was associate director. Leland B. Yeager, then assistant professor, was executive secretary.

21 He completed his dissertation in 1951 and its topic was The Extent of Enterprise Monopoly in the United States.

22 Stigler recounted the story as follows. Nutter "was scheduled to give a talk at Rochester at a workshop entitled something like, "The Fallacy of the Coase Theorem". But he made the mistake of taking a plane from Charlottesville and sitting next to Friedman and when he got to Rochester the paper was retitled "A New Proof of the Coase Theorem"' (Stigler, in Kitch, 1983, 227). 
result-the general form of which corresponded to the Coase theorem-and a model-the example of the rancher and the farmer used by Coase. Nutter's entire demonstration consisted of various numerical examples of the same nature as those used by Coase in the third section of his paper. Nutter ignored Coase's discussion of case law and real-world analysis. Quite interestingly, he did not even define or characterize liability. That remained completely implicit in his numerical, formal, abstract if not axiomatized, analysis. Thus, although he claimed that he was following and in fact defending Coase, Nutter was actually following and defending a caricature, seen only in the first three sections of PSC.

Thus, more broadly and to summarize this section, it can be said that besides Demsetz, none of the economists who referred to Coase, PSC and 'liability' really paid attention to the legal subtleties of the concept (sections V and VII), how courts had-according to Coase-done reasonably well in assigning liability in real world contexts with transaction costs (section VII), the fact that different regimes of liability or different social arrangements could have different economic consequences (sections VI), Coase's trenchant criticism of the Pigouvian tradition specifically for failing to engage in comparative analysis of alternative social arrangements based on 'the total social product yielded by the different social arrangements', (sections VIII and IX), and ultimately, Coase's call for a A New Approach (section X).

This might not be surprising in the first years of a decade in which 'law and economics' was not particularly successful-that is, economists were not particularly interested in legal issues and, reciprocally, legal scholars were not really receptive to the use of economics in their discipline. The situation, however, did not change in the second half of the decade. The context evolved and new problems arose — car accidents and questions about tort law-that were analyzed in a Coasean framework and in terms of externalities. Although cited, quoted or mentioned, Coase and PSC nonetheless remained exactly as they had previously been.

\section{Coase, law and economics, and accidents}

In the second half of the 1960s, a new situation emerged that could have opened up a new life for Coase and PSC. In effect, in the 1950s and 1960s, car accidents were a major problem in the USA. The number of accidents had dramatically increased as did the number of trials and court delays plaintiffs had to suffer before receiving compensation, which was usually insufficient. All this resulted in complaints about tort law and the US legal system and in strong claims about necessary reforms, the so-called 'auto-compensation plans'. The debates and discussions broadened and came to bear on liability rules at a more general level. Economic arguments were frequently used, even though all the debates and discussions mainly involved legal scholars (Calabresi, 1961; Conard, 1964; 
Ehrenzweig, 1954; Franklin, Chanin et Mark, 1961, for instance). Now, and this is where it becomes interesting, in those debates, harms were frequently modeled as externalities and accidents were analyzed in terms of 'social cost'-in the Pigovian terms to which Coase had given a new life. Calabresi, for instance, initiated this literature in 1961 and then engaged in a debate with the two Chicago law professors, Walter Blum and Harry Kalven. All referred to Coase and to PSC, disagreeing (Blum and Kalven, 1965, 1967) or partially agreeing (Calabresi, 1965, 1967, 1968b) with him.

For their part, economists took a very limited part in those debates, and their contributions did not really provide a precise analysis of Coase. For some reasons, which are not our objective to investigate, PSC remained invisible from the (rare) economists who examined these issues. This is why they are interesting. One of the first economists who discussed the impact of different legal liability rules on accidents was Simon Rottenberg in a 1965 article, 'Liability in Law and Economics', published in the American Economic Review. ${ }^{23}$ Despite its title, and although he distinguished negligence and strict liability (or liability without fault), Rottenberg did not refer to any recent economic literature, including Coase and PSC.

Rottenberg's conclusion-he advocated for a change 'from the present rule of limited liability of air carriers in international operations to one of unlimited liability' $(1965,113)$-was consistent with the changes that were occurring in the legal environment in the United States. In particular, negligence was being replaced by strict liability for product defects. In 1965, the American Law Institute insisted in article 402A of its Restatement of Torts that a strict liability rule should be adopted for all products. Such a change-consisting in shifting liability from consumers to producers-was of some importance for the economic consequences it could have. Precisely noting this evolution, that is the 'substantial and radical change, generally in the direction of shifting a large part of the cost of faulty goods back to the producer rather than leaving it with the consumer' (AEA-AALS, 1967, 716), ${ }^{24}$ the members of the ad hoc Joint Committee of the Association of American Law Schools and the American Economic Association, ${ }^{25}$ who met at Chicago on November 12, 1966, decided

23 Rottenberg was at that time a Professor of Economics at SUNY-Buffalo, having previously served on the faculty at Chicago. His 1956 article, 'The Baseball Players' Labor Market' developed a result akin to Coase's invariance claim with his contention that the structure of property rights over baseball players would not impact on the allocation of players across baseball teams.

24 The Joint Committee was set up to 'to explore the possibilities of collaborative efforts between the two organizations'. Three topics were envisaged for the conference: product liability, criminal law, and antitrust (report, AER, 1967). Product liability was chosen. A conference was planned for 1968, to be supported by the Walter E. Meyer foundation and it took place in March 1969.

25 The committee comprised eight members. The AEA was represented by Armen A. Alchian, Ronald H. Coase, Gerald M. Meier, George J. Stigler; the AALS was represented by Harlan M. Blake, Robert H. Bork, William A. Klein, James A. Rael, Henry G. Manne (Chairman of the committee). 
to organize a conference on Product Liability: Economic Analysis and the Law. Planned for 1968, the conference eventually took place in March 1969.

In the meantime, Oliver Williamson, Douglas Olson, and August Ralston published 'Externalities, Insurance, and Disability Analysis' (1967). This article must be included in this literature about accident harms as externalities. The authors used the recent literature on externalities, including PSC, to analyze disability, that is, harms sufficiently severe to create disability. Their contribution was the first paper to refer to PSC after Stigler named the Coase theorem. They studied three cases-automobile injury, radiation injury, and workers' compensation-to compare interactions in which individuals are linked by privity of contract and those in which there is no contractual relationship. This is important because the nature of the duties that exist between individuals depends on the nature of their legal relationship. The authors claimed that their idea to apply the externality model to 'aspects of human wealth which involve disability condition' $(1967,235)$ was original. They were not totally right even if one considers economists only, as seen above with Rottenberg's article. But Williamson, Olson, and Ralston made no reference to this 'legal' literature. They included references to some articles published in law reviews but only where convenient to illustrate their model. They did not discuss the legal content of the concepts they used, in particular the concept of liability. Once again, liability was simply viewed as a word borrowed from the legal scholars to describe a simple and general fact-that one individual may have to pay for the damage suffered by another individual. It is reduced to a binary and thus stripped of any legal content and contextual meaning. From this perspective, Williamson et al. did not differ from the other economists who mentioned Coase, cited PSC and referred to 'liability' generically as an element of Coase's analysis.

In 1968, the journal Law and Contemporary Problems organized a symposium on safety. Among the papers, written by legal scholars and economists, only two refer to Coase and to PSC; one of them had been written by an economist-Lester Lave. ${ }^{26}$ Lave cited PSC in relation of externalities (1968, 514 ) and also for having argued that the potential victim of an accident could always bribe the potential offender to act in a way that would prevent the damage $(1968,518)$. Thus, the references are of a slightly different nature than those made in the preceding articles. Nonetheless, with regard to the more nuanced dimensions of Coase's PSC, not much had changed.

Then, in June 1968, Demsetz presented at a meeting of the American Bar Association Special Committee on Auto Reparations a short piece developing his economic view on accidents. Of the work on the topic of accidents and liability rules, Demsetz was closest to appreciating Coase's nuanced argumentation and

26 The other was Guido Calabresi, who noted the connection between Coase's analysis and liability' $[r]$ egardless of who was initially liable, transactions would occur to change the behavior of every person so long as each change caused a greater reduction in accident costs than in pleasure'. (1968a, 437). 
to making deeper use of the legal concepts and case law. However, this fourpage long note included no references to the literature and Demsetz did not refer to actual legal rules. However, Demsetz displayed a genuine legal knowledge in particular in terms of liability rules. Such knowledge was also visible in the academic pieces Demsetz wrote at about the same time, such as 'Towards a Theory of Property Rights' (1967), 'When Does the Rule of Liability Matter?' (1972a) and 'Wealth Distribution and the Ownership of Rights' (1972b). In these articles, liability occupied a nonnegligible part of the analysis. But the way Demsetz referred to Coase did not change.

More globally, when the AALS-AEA conference about products liability took place, in March 1969, the way PSC was referred to had not changed since Turvey. The conference represented a genuine opportunity for reconsideration of PSC. It could have occurred had participants in the conference listened to, read and followed Roland McKean, the economist who had been invited to be the lead speaker and to write a monograph for the conference.

Not a law and economics specialist-none of the participants in the conference were specialists of a still nascent field-McKean nonetheless was close to Coase's ideas; he had already demonstrated an acquaintance with PSC. A former colleague of Coase and of Buchanan at the University of Virginia, McKean had been one of the first ${ }^{27}$ to propose a comparative institutional analysis similar to Coase's, analyzing the costs of markets with the costs of government interventions, market failures and government failures. Even if an invisible hand exists within governments too and 'tends to harness individual interests within government to carry out broader objectives' $(1965,504)$, one should also 'keep in mind the formidable imperfections of the mechanism'. (ibid.) Economists knew so little about the behavior of governments that it was premature and inopportune to conclude that a transfer of activities to the public sector would solve market failures (Hitch and McKean, 1961).

McKean adopted the same argumentation in 'Products Liability: Trends and Implications', which he presented at the conference and was published with the proceedings of the conference in the University of Chicago Law Review (UCLR) (1970a), and in a second version he wrote for an economic audience and was published in the Quarterly Journal of Economics (QJE) (1970b). Both papers started with the same assumption: (1) '(except in certain hypothetical circumstances) alternative arrangements will have different impacts on production processes, the purchase of insurance, the way particular resources are used, the allocation of resources, and the options open to consumers, as well as on fairness' (1970a, 4); (2) 'Alternative right assignments may have different impacts on equity (as conceived of by each individual) and, since there are transaction costs, different impacts on production processes and costs,

27 Medema (2014) shows that Coase and McKean were almost the only ones to develop this kind of analysis. Buchanan was a third one. 
insurance carried, the allocation of resources among uses, and the options open to consumers. In this article, I shall discuss some of those impacts of different right assignments pertaining to liability for damage'. (1970b, 612) In both papers, McKean stressed that he had the same objectives: 'the paper ... will simply trace out some of the consequences of products liability arrangements to determine whether commentators recognize the implications of different arrangements' $(1970 \mathrm{a}, 5)$ and 'I shall attempt ... simply to discuss some of the consequences of alternative products-liability arrangements' $(1970,615)$. Of course, he did more than performing a basic comparison between liability and no-liability, void of legal content, as the economists' papers discussed above had done. $^{28}$

McKean did not reduce the complex legal concepts to mere words. From this perspective, his article was the exact opposite of the economists' papers we discussed in the preceding section, and a perfect complement or echo to PSC. It was the same type of essay. In terms of economic analysis, McKean remained simple enough. He did not write a technical, abstract economic paper and presented a textbook type of analysis, based on simple arithmetic. The clarity and simplicity of the presentation of economic principles balanced the richness and density of the presentation of products liability, the various forms of the rule and the history and recent evolution of products liability. McKean displayed a real proficiency in examining the legal issues. Thus, the very same words Mishan had used to characterize PSC were perfectly appropriate to describe the UCLR version of McKeans's article and especially its first section, which was 'replete with legal cases'. ${ }^{29}$

In his analysis, McKean referred to Coase-in both the economic and the legal parts of the paper. He cited PSC as a reference to defend his claim that '[i]n developing special rules for these categories of products, the courts were probably groping, unconsciously, for changes in the assignment of rights that would yield more gain than cost' (1970a, 8). He also wrote that 'As Coase notes, such phrases as "Users must handle products with reasonable care" suggest that judges were seeking to weigh harm against utility' (1970a, 9, fn 18). Equally, McKean acknowledged directly that, in PSC, Coase had displayed a real legal knowledge, explicitly writing that Coase's suggestions about judicial behavior (1970a, 21) were grounded in an examination of 'statements by such authorities as Prosser and the language of several decisions in English and U.S. court' (1970a,

28 There is another difference between the two papers. In the QJE version, McKean added a precision, saying that 'products liability' is a problem of externality - 'accidental damages are a special case of externalities' (1970b, 611)—while the concept is only mentioned in passing in the UCLR version-in a footnote, referring to Williamson, Douglas and Rashton; and toward the end of the paper.

29 We are not particularly interested in defending Coase's or McKean's legal analysis. We have some concerns. But they are really beside the point developed in this article. Both Coase and McKean engaged with cases, the nuance of various formulations of legal rules, the importance of context, and comparative analysis. 
9, fn 77). To McKean, PSC could not be restricted to an abstract economic result. Its legal content was sufficiently reliable to be used as a source for McKean's own legal analysis. Similarly, the references McKean made to Coase's economic analysis also proved that he did not reduce PSC to the Stiglerian version of the Coase theorem. He referred to the 'fairly heroic' (McKean, 1970a, 31) zerotransaction costs assumption and stressed that they 'do not hold in the real world' (McKean, 1970, 31). But he also explained that, for Coase, it was only a starting point. McKean also used it as a starting point-comparing what would occur in an hypothetical world without transaction costs and what would occur in the real world.

To no avail, the idea that Coase could have had an economic discourse with nuanced legal dimensions received absolutely no echo among the conference participants. For completeness, we should distinguish what was written in the other contributions-the comments on McKean's article—and what was said during the discussion.

None of the two other economists (James Buchanan, Virginia Polytechnic Institute, and Robert Dorfman, Harvard) and two law professors (Calabresi, Yale, and Grant Gilmore, Chicago) who were asked to write comments on McKean's paper really paid attention to what Coase had written in terms of liability, nor to Coase's discussion of actual legal cases. Calabresi and Bass developed a rather detailed legal analysis but did not even mention Coase's name. This is no surprise. Calabresi and Bass had written a paper based on Calabresi's own work. In 1969, Calabresi had written extensively on how to assign liability in case of damage and had already argued, first, that ' $[t]$ here are naturally, some situations where ... it actually does not matter who bears the loss initially' (Calabresi, 1961, 506) but, second, that this 'presupposes an all- knowing, all rational economic world' (Calabresi, 1961, 506). The Calabresi/Bass paper simply made the same claim.

Gilmore, a law professor at University of Chicago at that time, based his comment on a legal analysis that was not directly related to what McKean had said. The reason is that he felt, as he said at the very beginning of this communication, that he was probably the less qualified lawyer in the United States that could have been chosen to discuss McKean's paper and wondered why he had been assigned such a task. He nonetheless mentioned Coase only through the reference made by McKean: 'I take it that everyone accepts as true the "theorem" scribed to my colleague, Professor Coase: that if transaction costs were zero and if all exchanges were voluntary ... it would not matter how the legal rights or liabilities were initially assigned for economic purposes' (Gilmore, 1970, 105; emphasis added). Then, Gilmore reasoned as if McKean had only analyzed the situations in which there are no transaction costs, which was not the case as shown earlier. In other words, McKean was accused of having committed the same (fictitious) sin as Coase simply because he used the same assumption as a starting point. 
Curiously enough, Dorfman made exactly the same points. First, he said that he was not qualified to discuss the legal issues involved with products liability'I suffer from the layman's disability of not really understanding what the legal issues are' $(1970,93)$ and 'I still feel that I must approach this paper without clearly comprehending what the legal side of the question is all about' (94). To him, 'lawyers and economists are bound to have difficulty in understanding each other's approach to this or any other topic' (92). He did not feel it was necessary for him to get into the legal dimension of McKean's analysis. What interested him was the zero transaction costs hypothesis with which he strongly disagreed. He started the paper by saying: 'I am very suspicious of the particular line of simplification that Professor McKean regards as being most illuminating. It will be recalled from reading Professor McKean's paper that his point of departure ... is to consider the problem in a much simpler world than ours, one in which there are no costs of gaining information or of negotiating contracts or of enforcement. That is a very useful conceptual device for some economic problems ... . But for other purposes that device can be grossly distorting' (1970, 94). He concluded that ' $[t]$ he problem of products liability arises because we live in a world in which it is costly to obtain full, or even adequate, information about the products we use. We cannot abstract from these costs without changing the problem in an essential manner' $(1970,98)$. (One can only imagine what McKean was thinking!)

In his contribution, Buchanan referred to the Coase theorem rather than Coase's or McKean's more substantive contributions. After having demonstrated that caveat emptor should be favored over caveat venditor-in a more affirmative way than what McKean had done-Buchanan tried to reconcile his result with the Coase theorem, according to which 'the absence of transaction costs the assignment of liability as between two parties to a potential transaction will not modify the final allocative result.' (Buchanan, 1970, 68) He concluded that, in his view, the Coase theorem was irrelevant to the situations he was analyzing. Buchanan's reference to the Coase theorem was useless, except as a straw man.

In terms of engaging what Coase had written in PSC, the outcome is quite poor, particularly given the opportunity that McKean presented. One might argue that none of these scholars was obliged to pay attention to what Coase had written since they were not discussing Coase's work. But they referred to his work and focused only on the toy model and its zero transaction costs assumption. This was even worse in the discussion that took place after the presentations. PSC was no more than the theorem, and as such, a rather clear target on their dartboard. Dorfman compared economics with physics and economists with 'ballistic experts': the law of gravity 'works best in a vacuum ... [but] ... is not helpful at all in predicting more terrestrial projectories' (Dorfman in Manne, 1978, 122; emphasis added); economists, like 'ballistics experts', are 'not concerned with problems in a vacuum' (Dorfman in Manne, 1970, 122; emphasis added) but are interested in 'actual markets' (Dorfman in Manne, 1970, 
122). Similarly, Gilmore, accepting McKean's claims, insisted on the necessity to acknowledge a difference 'between Professor Coase's world in which there are no transaction costs and all exchanges are voluntary and a world in which there are always transaction costs and few, if any, exchanges that are voluntary' (Gilmore, 1970, 106). He doubted that Coase's 'abstract theoretical analysis ... gives us, or is meant to give us, guidance in handling real problems in the real world' (Gilmore, 1970, 116). For his part, Stigler stepped in the discussion only to say that the validity of the Coase theorem should not be viewed an empirical problem-the existence or the absence of transaction costs. The Coase theorem is valid even if there are transaction costs because it is only a theorem. What can be said is that sometimes it applies and sometimes it does not. Thus, and this is what matters for our analysis, very rapidly_almost immediately after McKean answered the comments made by the other participants-the discussion veered off toward the validity of the Coase theorem. The legal, comparative, and contextual dimensions of Coase's analysis in PSC (as well as McKean's complementary analysis) were systematically ignored.

\section{Conclusion}

There is remarkable irony in the fact that the economics profession interpreted Coase's seminal article exactly the opposite of what he had intended, and essentially, in doing so, reduced his analytical contributions to a toy model of the exact sort he was criticizing. Coase complained that PSC was reduced to an abstract paper by his colleagues from Chicago who misunderstood him. Many scholars have studied the gap between Coase's article and how economists received it. It has largely been shown that Coase's message was broader than what is usually believed, and it deserved to be reassessed. ${ }^{30}$ The impact of Stigler's Coase theorem has also largely been studied. But as we show, Stigler was only one among many. Almost all of Coase's contemporaries in economics perceived and treated Coase's article in the same way. The reductionist phenomenon dated back to the very first references to PSC, made just after its publication. We document the ironic story of how PSC was transformed from 'a learned paper, replete with case law' into an abstract paper divorced from context and how the legal, comparative, and contextual dimensions of Coase's analysis were systematically ignored.

To set the record straight: Coase had little faith in the toy model of a zero transaction cost world; he did not champion property rights or any particular social arrangement over any other. ${ }^{31}$ Rather, he critiqued partial analyses

30 See recent reassessments by, in particular, Bertrand, 2006, 2009, 2010; Klaes, 2000; McCloskey, 1998; Medema, 1994; 1995; Medema and Samuels, 1997; Schlag, 2013.

31 Contrary to what many casual references to PSC suggest, 'Coase anticipated a role for government above and beyond defining and enforcing property rights, but he thought that role should be limited and 
and emphasized that it is 'desirable that the choice between different social arrangements for the solution of economic problems should be carried out in broader terms [than the value of production as measured by the market] and that the total effect of these arrangements in all spheres of life should be taken into account'. He strongly criticized both laissez faire and ideal world analyses and suggested that 'a better approach would seem to start our analysis with a situation approximating that which actually exists, to examine the effects of a proposed policy change and to attempt to decide whether the new situation would be, in total, better or worse than the original one'. In closing, we emphasize that to fully appreciate PSC, you should read it from back to front, section-bysection starting with $X$ : A Change of Approach.

\section{Acknowledgements}

Earlier versions were presented at the 2014 HES annual conference (Montreal, Canada) and at a seminar at the Federation University (Ballarat, Australia). We thank all the participants for their comments. Particular thanks go to Élodie Bertrand, Daniel Cole, Harold Demsetz, Henry Manne and Steve Medema for comments on a previous version of the paper. Alain Marciano acknowledges the support of the Hoover Chair in Ethics (Louvain-la-Neuve University) and of CIRHUS (CNRS-NYU) where he wrote and revised the paper.

\section{References}

AEA-AALS. (1967), 'Report of the Joint Committee of the American Economic Association and the Association of American Law Schools', American Economic Review, 57(2): $715-717$.

Bertrand, É. (2010), 'The Three Roles of the “Coase Theorem” in Coase's Works', European Journal of History of Economic Thought, 31(1): 39-62.

Bertrand, É. (2006), 'The Coasean Analysis of Lighthouse Financing: Myths and Realities', Cambridge Journal of Economics, 30(3): 389-402.

Bertrand, É. (2009), 'Empirical Investigations and their Normative Interpretations: A Reply to Barnett and Block', Public Choice, 140(1-2): 15-20.

Blum, W. J. and H. Kalven, Jr. (1964), 'Public Law Perspectives on a Private Law Problem: Auto Compensation Plans', University of Chicago Law Review, 31(4): 641-723.

Blum, W. J. and H. Kalven, Jr. (1965), Public Law Perspectives on a Private Law Problem: Auto Compensation Plans, Boston: Little, Brown \& Company.

Blum, W. J. and H. Kalven, Jr. (1967), 'The Empty Cabinet of Dr. Calabresi: Auto Accidents and General Deterrence', University of Chicago Law Review, 34(2): 239-273.

Borcherding, T. E. (1970), 'Liability in Law and Economics: Note', American Economic Review, 60(5): 946-948. 
Buchanan, J. M. (1956), 'Private Ownership and Common Usage: The Road Case ReExamined', Southern Economic Journal, 22(3): 305-316.

Buchanan, J. M. (1970), 'In Defense of Caveat Emptor', University of Chicago Law Review, 38(1): 64-73.

Buchanan, J. M. and W. C. Stubblebine (1962), 'Externality', Economica, 29(116): 371-384.

Calabresi, G. (1961), 'Some Thoughts on Risk Distribution and the Law of Torts', Yale Law Journal, 70(4): 499-553.

Calabresi, G. (1965), 'The Decision for Accidents: An Approach to Nonfault Allocation of Costs', Harvard Law Review, 78(4): 713-745.

Calabresi, G. (1965), 'Fault, Accidents and the Wonderful World of Blum and Kalven', Yale Law Journal, 75(2): 216-238.

Calabresi, G. (1968a), 'Transaction Costs, Resource Allocation and Liability Rules-A Comment', Journal of Law and Economics, 11(1): 67-73.

Calabresi, G. (1968b), 'Does the Fault System Optimally Control Primary Accident Costs?', Law and Contemporary Problems, 33(3): 429-463.

Calabresi, G. and K. C. Bass, III. (1970), 'Right Approach, Wrong Implications: A Critique of McKean on Products Liability', University of Chicago Law Review, 38(1): 7491.

Castle, E. N. (1965), 'The Market Mechanism, Externalities', Journal of Farm Economics, 47(3): 542-556.

Coase, R. H. (1960), 'The Problem of Social Cost', Journal of Law and Economics, 3(October): 1-44.

Coase, R. H. (1988), The Firm, the Market, and the Law, Chicago, IL: University of Chicago Press.

Coase, R. H. (1993), 'Law and Economics at Chicago', Journal of Law and Economics, 36(1): 239-254.

Coase, R. H. (1996), ‘The Problem Of Social Cost: The Citations', Chicago-Kent Law Review, 71: 809-812.

Cole, D. H. (2014), 'The Law \& Economics Approach to Property', Indiana Legal Studies Research Paper No. 277. Available at SSRN: http://ssrn.com/abstract=2375933, Property Law Review (forthcoming).

Conard, A. (1964), 'The Economic Treatment of Automobile Injuries', Michigan Law Review, 63(2): 279-326.

Demsetz, H. (1962), 'The Effect of Consumer Experience on Brand Loyalty and the Structure of Market Demand', Econometrica, 30(1): 22-33.

Demsetz, H. (1964), 'The Exchange and Enforcement of Property Rights', Journal of Law and Economics, 7: 11-26.

Demsetz, H. (1966), 'Some Aspects of Property Rights', Journal of Law and Economics, 9: 61-70.

Demsetz, H. (1967), 'Toward a Theory of Property Rights', American Economic Review, 57(2): 347-59.

Demsetz, H. (1968), 'The Cost of Transacting, Quarterly Journal of Economics, 82(1): 33-53.

Demsetz, H. (1969), 'Information and Efficiency: Another Viewpoint', Journal of Law and Economics, 12(1): 1-22.

Dorfman, R. (1970), 'The Economics of Products Liability: A Reaction to McKean', University of Chicago Law Review, 38(1), 92-102.

Ehrlich, I. (1973), 'Participation in Illegitimate Activities-A Theoretical and Empirical Investigation', Journal of Political Economy, 81(3): 512-565. 
Ehrlich, I. (1975), 'The Deterrent Effect of Capital Punishment-A Question of Life and Death', American Economic Review, 65(3): 397-417.

Franklin, M. A., R. H. Chanin and I. Mark (1961), 'Accidents, Money, and the Law: A Study of the Economics of Personal Injury Litigation', Columbia Law Review, 61(1): 1-39.

Frischmann, B. (2007), 'Evaluating the Demsetzian Trend in Copyright Law', Review of Law and Economics, 3(3): 649-677.

Frischmann, B. M. and M. A. Lemley (2007), 'Spillovers', Columbia Law Review, 107(1): 257-301.

Gilmore, G. (1970), 'Products Liability: A Commentary', University of Chicago Law Review, 38(1): 103-116.

Halpin, A. (2011), 'Coase's world and Coase's blackboard', European Journal of Law and Economics, 31(1): 91-109.

Harnay, S. and Alain Marciano. (2009), 'Posner, Economics and the Law: From Law and Economics to an Economic Analysis of Law', Journal of the History of Economic Thought, 31(2): 215-232.

Hitch, C. J. and R. N. McKean (1961), 'What can Managerial Economics Contribute to Economic Theory?', American Economic Review, 51(2): 147-154.

Kitch, E. W. (1983), 'The Fire of Truth: A Remembrance of Law and Economics at Chicago, 1932-1970', Journal of Law and Economics, 26(1): 163-234.

Klaes, M. (2000), 'The History of the Concept of Transaction Costs: Neglected Aspects', Journal of the History of Economic Thought, 22(2): 191-216.

Landes, W. M. (1968), 'The Economics of Fair Employment Laws', Journal of Political Economy, 76(4): 507-552.

Landes, W. M. (1971), 'An Economic Analysis of the Courts', Journal of Law and Economics, 14(1): 61-107.

Lave, L. B. 'Safety in Transportation: The Role of Government', Law and Contemporary Problems, 33(3): 512-535.

Manne, H. G. (1970), 'Edited Transcript of AALS-AEA Conference on Products Liability', University of Chicago Law Review, 38(1): 117-141.

McCloskey, D. N. (1998), 'The So-Called Coase Theorem', Eastern Economic Journal, 24(3): 367-371.

McKean, R. (1970a), 'Products Liability: Trends and Implications', University of Chicago Law Review, 38(1): 3-63.

McKean, R. (1970b), 'Products Liability: Implications of Some Changing Property Rights', Quarterly Journal of Economics, 84(4): 611-626

Meade, J. E. (1952), 'External Economies and Diseconomies in a Competitive Situation', Economic Journal, 62(245): 54-67.

Medema, S. G. (1994), Ronald H. Coase, New York: St. Martin's Press.

Medema, S. G. (1995), The Legacy of Ronald Coase in Economic Analysis, Brookfield: Edward Elgar.

Medema, S. G. (2013), 'The Importance of Being Misunderstood: The Coase Theorem and the Legacy of "The Problem of Social Cost"', Journal of Natural Resources Policy Research 5: 249-253.

Medema, S. G. (2014a), 'The Curious Treatment of the Coase Theorem in Environmental Economics 1960-1979', Review of Environmental Economics and Policy, 8: 39-57.

Medema, S. G. (2014b), 'Neither Misunderstood Nor Ignored: The Early Reception of Coase's Wider Challenge to the Analysis of Externalities', History of Economic Ideas (forthcoming). Available at SSRN: http://ssrn.com/abstract $=2479729$ 
Medema, S. G. (2014c), 'Debating Law's Irrelevance: Legal Scholarship and the Coase Theorem in the 1960s', Texas A\&M Law Review (forthcoming).

Medema, S. G. and W. J. Samuels (1997), 'Ronald Coase and Coasean Economics: Some Questions, Conjectures and Implications', in W. Samuels, S. Medema and A. Schmid (eds.), The Economy as a Process of Valuation, Cheltenham, UK: Edward Elgar, pp. 72-128.

Miller, L. H. (1962), 'On the “Chicago School of Economics”', Journal of Political Economy, 70(1): 64-69.

Milliman, J. W. 'Can People Be Trusted with Natural Resources?', Land Economics, 38(3): 199-218.

Nutter, G. W. (1968), 'The Coase Theorem on Social Cost: A Footnote', Journal of Law and Economics, 11(2): 503-507.

Posner, R. A.. (1972), 'A Theory of Negligence', Journal of Legal Studies, 1(1): 29-96.

Posner, R. A. (1993), 'Ronald Coase and methodology', Journal of Economic Perspectives, 7: 195-210.

Rottenberg, S. (1956), 'The Baseball Players' Labor Market', Journal of Political Economy 64: $242-258$.

Rottenberg, S. (1965), 'Liability in Law and Economics', American Economic Review, 55: 107-114.

Schlag, P. (2013), 'Coase Minus the Coase Theorem. Some Problems with Chicago Transaction Cost Analysis', Iowa Law Review, 99, 175-222 (Available at SSRN: http://ssrn.com/abstract=2320068).

Scitovsky, T. (1954), 'Two Concepts of External Economies', Journal of Political Economy, 62(2): 143-151.

Stigler, G. J. (1966), The Theory of Price, New York: Macmillan.

Stigler, G. J. (1971), 'The Law and Economics of Public Policy: A Plea to the Scholars', Journal of Legal Studies, 1(1): 1-12.

Stigler, G. J. (1988), Memoir of an Unregulated Economist, Chicago, IL: University of Chicago Press.

Stigler, G. J. (1989), ‘Two Notes on the Coase Theorem', Yale Law Journal, 99(3): 631-633.

Turvey, R. (1963), 'On Divergences between Social Cost and Private Cost', Economica, 30(119): 309-313.

Wellisz, S. (1964), 'On External Diseconomies and the Government-Assisted Invisible Hand', Economica, 31(124): 345-362. 